\title{
A review of effective interventions for reducing and controlling obesity in primary school children
}

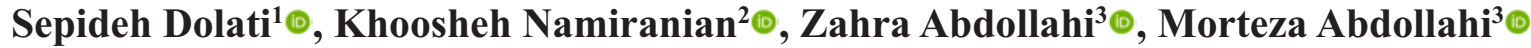

${ }^{1}$ Department of Nutrition, Ministry of Health \& Medical Education, Tehran, Iran

${ }^{2}$ Sport Physiologist, Undersecretary of Health; Tehran University of Medical Sciences, Tehran, Iran

${ }^{3}$ Department of Nutrition, Ministry of Health, Tehran, Iran

${ }^{4}$ Social Determinants of Health Research Center, Shahid Beheshti University of Medical Sciences, Tehran, Iran

\begin{abstract}
Objectives: The prevalence of obesity has been doubled among children over the past 10 years, which will result in an obese population and its complications in near future. This situation can impose great costs on the health system and community for treating those obese people. The purpose of this review is to examine the effective strategies for reducing and controlling obesity in primary school students.

Methods: This review was conducted in August and September 2017. Our goal was to review the related articles in the authorized databases, including Scientific Information Center (SIC), Scholar Google, Scopus, and PubMed, from 2000 onward, by two researchers, considering language constraint (only English articles with full text were accepted). Out of 104,658 articles, 15 articles were excluded due to the lack of full text, and finally 25 articles were selected.

Results: The results of the existing studies showed that through involving parents, schools officials and continuous supporting measures like prohibition of long-term food advertising in television programs, all three educational, nutritional and physical activity interventions can help in controlling and reducing obesity.

Conclusions: To succeed in reducing and controlling obesity among students, especially primary school ones, the approaches and interventions should be implemented in three levels: home, school, and community.

Keywords: Obesity, overweight, community-based program, primary school children, school-based intervention
\end{abstract}

$\mathrm{T}$ he prevalence of childhood obesity has increased more than three times in the world over the past 30 years [1]. According to the statistics from 1980 to 2013, the prevalence of obesity among children has increased by $47.1 \%$ worldwide [2]. Previously, the problem of obesity and overweight was only for highincome countries, while the problem is rising in low and middle-income countries too, especially in urban areas that are facing nutrition transition and reduced physical activity [3-5]. Nutrition transition is generally associated with increased consumption of high energy and low fiber food, sweetened drinks, reduced physical activity and a more sedentary lifestyle [6]. A wide range of behavioral and environmental factors contributeto prevalence of obesity, including fast foods consumption, decreased physical activities due to watching TV, using computers and other electronic entertainments, increased consumption of high-calorie food products, and increasing sedentary jobs [7]. Iran, like many other developing countries, has experienced 
overweight and obesity in recent years, due to decreased physical activitiesand nutritional patterns changes [8]. According to National Integrated Micronutrient Survey (NIMS) study in 2011, overweight and obesity were reported in 7.9 and $5.6 \%$ of 6 year old children, respectively [9]. Also, the prevalence of overweight among 7-10 and 11-14 year old children were 8.2 and $10.2 \%$, and obesity was 11.1 and $12.2 \%$, respectively [10].

Children's obesity is associated with increased psychological factors such as low self-esteem, social alienation, risk of metabolic syndrome, high blood pressure and type 2 diabetes in adolescence. In addition, an obese child is more likely to become an obese adult $[6,8]$, so that more than 80 percent of adults with obesity, have been overweight in childhood and adolescence [11]. It is difficult to change the behavior in adulthood, so, prevention and control of obesity in childhood and adolescence will be more effective in preventing obesity and its complications in adulthood [12]. Some school-based interventions onchildren between 6 and 12 years old showed a positive effect on the prevalence of overweight or obesity $[12,13]$. Periodic interventions, preferably for 3 years, and parent involvement as a primary intervention target, can help in reducing obesity [14]. Although schools are known as an ideal environment for obesity prevention, systematic reviews and meta-analysis have shown different outcomes regarding the effectiveness of school-based interventions for the treatment and prevention of obesity in children [15]. The results of a study in Korea has shown a school-based obesity control program based on behavior modification and selfefficacy can be effective in decreasing obesity and increasing diet's self-efficacy [16]. Several studies have concluded that school-based interventions, with diet and physical activity can prevent overweight among children in long term, while physical activity interventions, especially in elementary schools, may be more effective in preventing overweight among children in the short term [15].

Therefore, the assessment of such studies plays an important role in identifying and controlling the risk factors associated with obesity in children. This study aimed to identify the best programs and interventions in students of elementary schools in order to control and reduce the incidence of obesity.

\section{METHODS}

This review study was conducted in August and September of 2017. In this review, the stakeholders' perspectives and interventions have been studied in three fields of education, physical activity and nutrition, for controlling, reducing and preventing of obesity among children of primary schools in three levels of school, family and society.

Relevant literature in English was identified through electronic search of papers published from 2000 onwards, in SID, scholar Google, Scopus and PubMed. The articles were reviewed by two reviewers. The Keywords used in the research were obese, weight, overweight, primary school children, control, prevent, intervention, control obesity in elementary school children, control of obesity among primary school children, intervention and control of obesity among elementary school children, and intervention and control of obesity among primary school children. Our search was limited to include entries from 2000 to 2017. The searches yielded 104,658 articles. 13 articles were excluded because they did not have full text. Finally, 25 articles were included (Fig. 1).

\section{RESULTS}

The selected topics were categorized into 5 groups: (1) Physical activity interventions, (2) Schoolbased interventions for obesity prevention, (3) Education-based and physical activity interventions for preventing obesity (With emphasis on nutrition in schools), (4) Nutrition education-based and physical activity interventions for obesity prevention, and (5) Nutrition-based and physical activity interventions to prevent obesity.

\section{Physical Activity Interventions}

In the study of Donnelly et al. [17], that examined the promotion of physical activity for weight loss and obesity in children over 3 years, the results showed that there was significant difference in BMI in the intervention group compared to the control group. Of course, schools with more than 75 minutes per week of physical activity had fewer increases in BMI than 


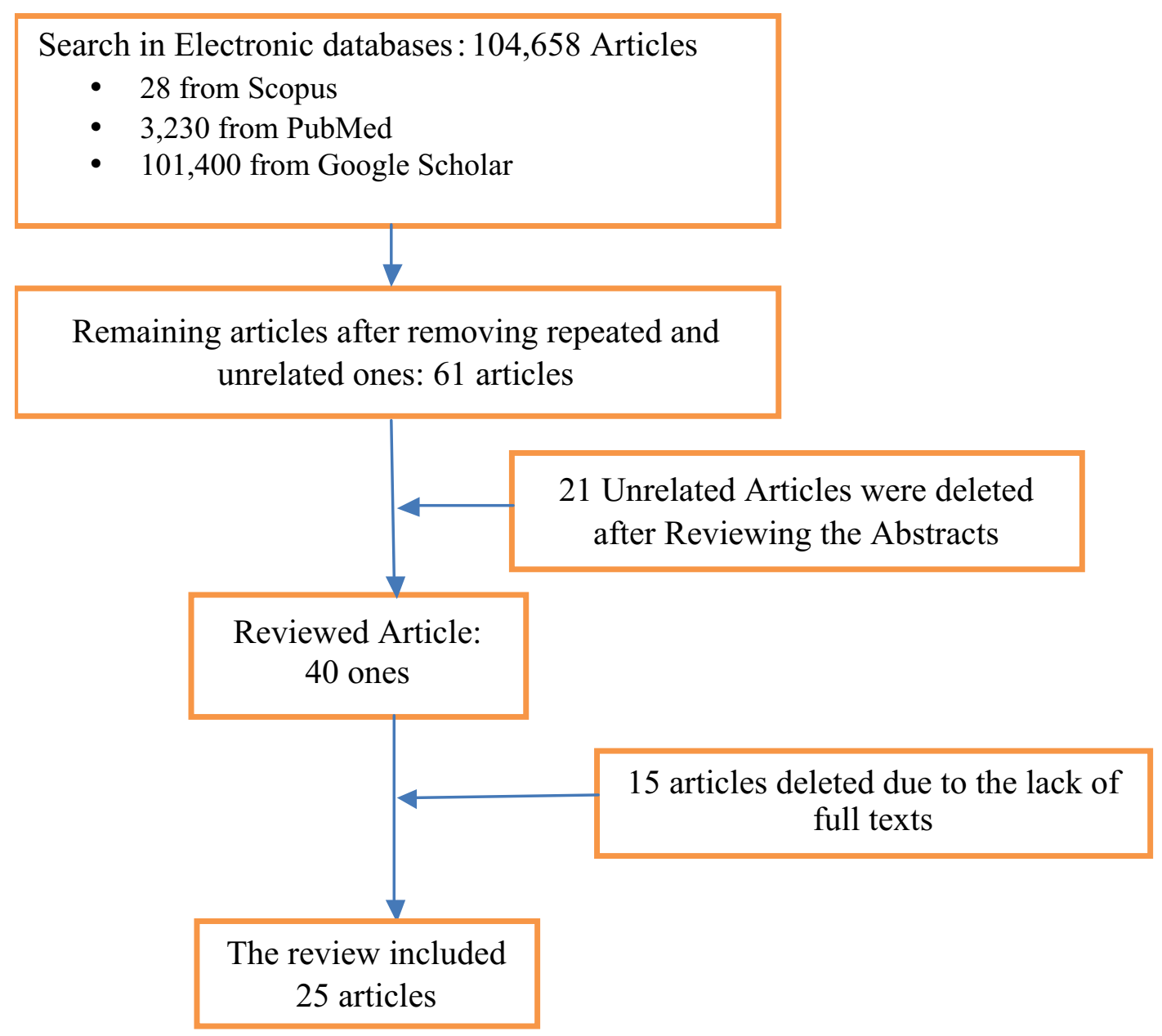

Fig. 1. Flow chart showing the process of screening and selecting the appropriate articles.

schools with less than 75 minutes per week.

In another study, Elizondo-Montemayor et al. [18] showed that physical activity in times out of school (3 days per week and 90 minutes each session) did not affect the BMI, and there was no significant difference in the BMI of the intervention and control groups. However, the percentage of skin fold and body fat percent significantly decreased in both girls and boys.

Yin et al. [19] studied the effects of an obesity program based on a "fit kid" exercise program without a dietary energy limitation for 3 years. In that program, physical activity intervention included 80 minutes of physical activity appropriate for children who routinely attended in daily school program and the out-of-school program included 120 minutes, 40 minutes for eating snacks, 40 minutes for home works and 40 minutes for physical activity (on holidays without home work, 80 minutes for physical activity). The results of that study showed that percentage of body fat decreased and cardiovascular and pulmonary function improved in the intervention group compared to control group in the first and second years, but did not have any significant effect on cholesterol (LDL and HDL) and BP levels.

Kriemler et al. [20] assessed the result of a oneyear survey in a multicomponent physical activity program that included the three compulsory weekly physical activity programs ( 3 times a week and 45 minutes each time) and the two additional weekly programs ( 2 times in every two days in week and 45 minutes each time), and in addition, three to five short activity programs (two to five minutes each day) during break times. These physical activities included motor skill tasks such as jumping or balancing on one leg, power games, or coordinative tasks. The result of that study showed that this multidisciplinary intervention improved fitness, reduced fat accumulation, and improved aerobic performance. Also, severe and moderate physical activity increased in school and also in overall physical activity, 
similarly. Z scores did not change significantly for everyday physical activity and for the quality of physical and psychological patterns of life.

\section{School-based Interventions for Obesity Prevention}

In a study by Cawley et al. [21] who examined the effect of physical activity training on obesity among obese adolescent school children, showed a reduced BMI Z-score and likelihood of obesity among primary school students, especially boys, with increase in the duration of physical activity classes.

Lynch et al. [22] implemented the standard curriculum of 0-1-2-5 (with the goal of consuming 0 sugar-containing drinks, including soda, juice, and sport drinks, participate in at least 1 hour physical activity, limit recreational times to 2 or fewer hours and eating 5 servings of fruits and vegetables) in second and third grade students, over a four-month period. Results of that study showed that there was no statistical difference in improvement of healthy habits, BMI or physical activity in the intervention group compared to the control one.

In Toruner and Savaser study [23] that performed educational interventions (parents and students training on improving diet and exercise habits, increasing physical activity outside of school and reducing TV watching and computer games) on obese and overweight students over a 2.5 month period, it was shown that body mass index (BMI) after 1 year of study significantly decreased in intervention group compared the control group $(p<0.05)$.

Fairclough et al. [24] performed the training-based interventions within 20 weeks, as educational class for teachers, parents and students, including healthy life, time and types of effective physical activity, the effect of technology on health and life, balancing energy and carbohydrate and sweet drinks consumption, fight with the hidden fat, increasing the consumption of fruits and vegetables, having high value breakfast, and reducing unhealthy food and snacks. The results of that study showed that BMI and waist circumference decreased, fruits and vegetables intake increased in breakfast meal, and physical activity of students and children's sleep improved.

In Xu et al.'s study [25], the results of educational interventions, including healthy eating and appropriate physical activity, school support, family participation and amusement programs likehealth classes for parents and children showed there was no significant difference in the BMI of the intervention group compared to the control group; but in the intervention group, decreased BMI about $0.5 \mathrm{~kg} / \mathrm{m} 2$ or more, increased distance of running, decreased watching TV and computer use, decreased consumption red meat, walking instead of using a car or service, compared tothe control group were seen.

In a study by Fernandes et al. [26], the results of educational interventions -eight educational meetings for 84 minutes on healthy diets, how to make healthy snacks, Pyramid of foods and food groups training, physical activity through games, reading poetry, photography and painting, puppet shows and group plays- showed the percentage of overweight/obese students in intervention groups increased from 21.8 to $23.6 \%$ and in non-interventional groups increased from 33.7 to $35.0 \%(p>0.05)$. The intervention group significantly reduced the intake of artificial juice ( $p=$ 0.013 ) and law-prohibited foods. In the control group, there was a significant increase in prohibited foods intake, such as salty snacks $(p=0.021)$ and freeze foods $(p=0.031)$. Also, intake of breakfast cereal and school snacks decreased $(p=0.039)$

In the study of Stock et al. [27], the results of education-based interventions (Teacher training for older students, and also training of younger students by older ones, 2-3 hours a week for 21 weeks on nutrition, physical activity and healthy body image) showed increase in healthy-living knowledge, behavior, and attitude scores in both older and younger intervention students and a smaller increase in systolic blood pressure, compared to the control group. BMI and weight increased less (in 4th through 7 th grade) and height increased more in the younger intervention students (students of kindergarten through 3rd grade). The knowledge not only improved in older students, but also in younger ones. It also led to a slower rate of weight gain among older students.

\section{Education-based and Physical Activity} Interventions for Obesity Prevention (with emphasis on nutrition in schools)

Of the selected papers in the five studies, nutritional education interventions have focused on school nutrition (buffet, lunch, etc.) and physical activity, simultaneously. 
In a study by Hollar et al. [28], the results of the interventions including diet-based ones (breakfast, lunch and snacks with an emphasis on the consumption of more vegetables, whole grains and reduced trans fatty acids), education-based ones (school officials or managers, teachers and food providing officials) and increased physical activity (at least 150 minutes per day in the first year, more than 1000 steps per day for the second year, and 5 to 10 minutes physical activity in the classroom and physical activity outside the school) were assessed over 2 years. Result of this assessment showed no significant change in BMI, but the BMI was lower in the intervention group (4.4\%) than in the control group $(2.5 \%)$. Also, the students in the intervention group were significantly higher in math's scores in each two years.

In a study by Kain et al. [29], the results of a 6month education-based intervention (training for school buffet officials and parents, a school curriculum including informing on healthy food), physical activity (providing more than 90 minutes active physical activity for 15 minutes a day, such as dancing, ping pong, basketball and volleyball) and incentive interventions (awarding students who intake a healthy diet during a day) were investigated. It was shown that these interventions had a positive effect on the obesity indices among boys (BMI z-score, waist circumference, but not ontricepsskin fold).

In Going et al.'s study [30], the results of over 2 years nutrition-based interventions (food delivery such as nuts, cheese sandwiches, yogurt and non-fat milk, non-sugar biscuits, fresh and dried fruits, juices and sugar-free drinks, providing low-calorie mineral water and low-calorie snacks), strategies to promote the sale of healthy foods such as placing healthy foods in view and installing boards to provide information on healthy food patterns, educational interventions (training teachers, students and buffet operators about the provision of healthy and hygienic foods) and physical activity interventions (90 minutes of weekly sports classes at moderate and severe physical activity levels) showed no significant difference in the two groups, but boys were 17 to 21 percent more active than girls.

Sahota et al. [31], evaluated the effectiveness of school-based interventionson reducing risk factors of obesity. They studied 10 primary schools in Leeds that consisted of 634711 year old children. They measured outcomes of body mass index, physical activity, diet and psychological state. Interventions of that study included teachers'education, modification of school meals, and development of school practice plans aiming the curriculum, physical education, tuck shops, and playing field activities. The consumption of vegetables in children is one of the main challenges of their diet. Implementation of that program led to a modest increase in the consumption of vegetables in intervention children. The result showed that fruit consumption was lower in obese children of the intervention group than those in the control group, while high sugar foods consumption was higher in overweight children of intervention group than control group. There was no difference in BMI and dieting behavior between the groups.

Bustos et al. [32] performed interventions over two years. The intervention modes consisted of nutrition education-based ones (inclusion of nutrition education in the curriculum with the goal of improving healthy eating knowledgeand habits, establishinga healthy kiosk by the healthy food delivery, including nuts and sandwiches of fresh cheese with tomatoes, fat free yogurt and milk, milk-based desserts, jelly, sugar-free biscuits, cereals, fresh and dried fruits, juices and sugar free drinks, mineral water and other low-calorie snacks) andproviding optimal physical activity through organizing physical education classes by a physical education teacher (70 minutes) whichhalf of thatspent on moderate to severeactivities. The results showed that implementing these interventions by each other, is more effective than doing themalone, in the control of obesity among6 to 10 year old children.

\section{Nutrition education-based and physical activity interventions for obesity prevention}

Of the selected papers, 9 studies were performed three interventions, namely physical training, nutrition and physical activity, simultaneously.

The results of a two-year intervention based on pediatric education (reducing sweetened drinks, increased fruit and vegetable intake), daily physical activity (walking), and healthy lifestyle interventions (encouraging healthy food consumption, increasing activity levels, Children's participation in housework and outdoor games) were assessed by Taylor et al. 
[33]. The results showed that the BMI in the intervention children was lower than the control group. However, there was no difference in the prevalence of overweight between the two groups. Waist circumference, systolic blood pressure, and consumption of carbonated beverages $(67 \%$ compared to the control group) had decreased in intervention group. In contrast, the consumption of fruits and nonsynthetic juices had increased [33].

The three years study of Tarro et al. [34] in three levels of education (using pamphlets and training classes for parents, students and teachers), nutrition (encouraging the use of healthy drinks, vegetables, legumes, fresh fruits and nuts, dairy and fish, and decreasing the consumption of carbonated soft drinks, candy and sweets) and physical activity (walking to school, play ground games, increasing physical activity and playing for 1 hour a day) showed that the prevalence of obesity in the intervention group decreased by $0-36.2 \%$ and increased by $2.3 \%$ in the control group. Among the boys, BMI z-score decreased significantly.

Kocken et al. [35], during two years of study, included nutrition (reduced consumption of highcalorie and high-fat foods and sugar-sweetened beverages, promoting a healthy breakfast, increasing fruit and vegetable consumption), physical activity (reducing television watching and computer gaming/browsing, increasing physical activity atand outside school, daily additional activities for engaging with parents and exercise education), and education (group discussions on healthy nutrition and homework assignments) interventions. The results of that two year study showed that in the intervention group, the students' awareness significantly increased compared to the control group and the duration of inactivity in the intervention group was significantly lower than the control group.

Perman et al. [36] were implemented an afterschool community-based obesity prevention and intervention program in an elementary school. The school's children with a BMI $>85^{\text {th }}$ percentile, were targeted. The students met the fun physical activities, proper nutritional information, and small group sessions with pediatric psychiatry residents focusing on good choices and proper motivations in life, twice a week, for 90-minute sessions. Findings after the first year of the intervention showed a slowing in the average rate of weight gain in children. A statistically significant difference $(p=0.027)$ was observed in mean BMI percentile for the targeted children. Based on this study, it seems that school-based preventing intervention conducted by a coalition of community agencies and organizations is a promising and costeffective approach to reduce the prevalence of obesity among children.

Jansen et al. [37] conducted an study to evaluate the effect of a school-based intervention program to reduce overweight. The intervention was a multicomponent intervention based on behavioral and ecological models. This intervention was implemented in two fields; educational (classroom instruction on healthy nutrition, active lifestyle and healthy lifestyle choices) and physical activity (three hours per week in exercise classes, 5 hours per week in outside school). The results of that intervention showed that the prevalence of overweight increased by $4.3 \%$ in the control group and by $1.3 \%$ in the intervention group. No significant effects were found for BMI. Also, the sport skills in the children of the intervention group increased.

Rito et al. [38] performed a 6-month period intervention based on education (classes for parents and students by nutritionists, healthy eating counseling for overweight and obese students and encouraging healthy foods), physical activity (at least one hour each day) and nutrition (nutrition education to gain skills and behaviors related to fields such as food preparation, food preservation and storage, social and cultural aspects of food and eating and other consumer aspects, and focus on increasing the consumption of fruits and vegetables and reducing sugary drinks and healthy cooking workshop with the presence of parents and students aimed at encouraging healthy eating). The study showed that the total consumption of fruits and vegetables reached 400 grams per day, fiber consumption increased, the consumption of beverages decreased, physical activity increased and watching TV time decreased to 2 hours per day.

In a multi-centered randomized controlled trial, $\mathrm{Li}$ et al. [39] aimed to evaluate the possibility and effectiveness of the comprehensive intervention program (combination of nutrition and physical activity interventions) for childhood obesity. In that study, three interventions were contained: nutrition education, physical activity and comprehensive 
Table 1. Intervention studies evaluating the effect of interventions on BMI, obesity and other criteria

\begin{tabular}{|c|c|c|c|c|}
\hline Author [Ref.] & Study & Intervention & $\begin{array}{l}\text { Duration of } \\
\text { intervention }\end{array}$ & Result \\
\hline Donnelly et al. [17] & $\begin{array}{c}\text { Randomized } \\
\text { controlled study }\end{array}$ & $\begin{array}{l}75 \text { minutes of physical } \\
\text { activity per week }\end{array}$ & 3 years & significant difference in BMI \\
\hline $\begin{array}{c}\text { Elizondo-Montemayor } \\
\text { et al. [18] }\end{array}$ & $\begin{array}{l}\text { Randomized } \\
\text { controlled trial }\end{array}$ & $\begin{array}{l}\text { Increase physical } \\
\text { activity during school } \\
\text { hours }\end{array}$ & 10 months & $\begin{array}{l}\text { There was no significant difference in } \\
\text { BMI but decreased the percentage of } \\
\text { skin and body fat percentage in both } \\
\text { genders }\end{array}$ \\
\hline Yin et al. [19] & $\begin{array}{c}\text { cluster } \\
\text { randomization design }\end{array}$ & $\begin{array}{l}\text { Increased physical } \\
\text { activity during school } \\
\text { hours }\end{array}$ & 3 years & $\begin{array}{l}\text { Decreased body fat percentage, } \\
\text { improved cardiovascular and } \\
\text { pulmonary function, no effect on } \\
\text { HDL, LDL, BP }\end{array}$ \\
\hline Kriemler et al. [20] & $\begin{array}{l}\text { cluster } \\
\text { randomized } \\
\text { controlled trial }\end{array}$ & $\begin{array}{l}\text { Increased physical } \\
\text { activity }\end{array}$ & 1 year & $\begin{array}{l}\text { Improvedfitness, reduced fat } \\
\text { accumulation, and improved aerobic } \\
\text { performance }\end{array}$ \\
\hline Cawley et al. [21] & Cohort & $\begin{array}{c}\text { Increased physical } \\
\text { activity }\end{array}$ & 1 year & Decreased BMI -z score \\
\hline Lynch et al. [22] & $\begin{array}{l}\text { cluster randomized } \\
\text { controlled field trial }\end{array}$ & $\begin{array}{l}\text { Nutrition and physical } \\
\text { activity education, } \\
\text { decreased computer } \\
\text { games and TV watching } \\
\text { and nutrition }\end{array}$ & 4 months & $\begin{array}{c}\text { There wasno significant difference in } \\
\text { the improvement of BMI and physical } \\
\text { activity }\end{array}$ \\
\hline $\begin{array}{c}\text { Toruner and Savaser } \\
{[23]}\end{array}$ & $\begin{array}{l}\text { Randomized } \\
\text { controlled trial }\end{array}$ & $\begin{array}{l}\text { Education for modifying } \\
\text { food patterns, increasing } \\
\text { physical activity and } \\
\text { decreasing computer } \\
\text { games and TV watching }\end{array}$ & 2.5 months & Decreased BMI \\
\hline Fairclough et al. [24] & $\begin{array}{c}\text { randomized } \\
\text { intervention study }\end{array}$ & $\begin{array}{l}\text { Modified food pattern } \\
\text { education and physical } \\
\text { activity }\end{array}$ & 20 weeks & $\begin{array}{l}\text { Decreased BMI and waist } \\
\text { circumference, increased fruit and } \\
\text { vegetable consumption in breakfast, } \\
\text { increased physical activity, and } \\
\text { children's sleep pattern }\end{array}$ \\
\hline $\mathrm{Xu}$ et al. [25] & $\begin{array}{l}\text { cluster randomized } \\
\text { controlled trial }\end{array}$ & $\begin{array}{c}\text { Healthy food patterns } \\
\text { education }\end{array}$ & 9 months & $\begin{array}{l}\text { No significant change in BMI, } \\
\text { reduced TV watching time and } \\
\text { computer games, reduced } \\
\text { consumption of red meat, increased } \\
\text { mobility and increased running } \\
\text { distance }\end{array}$ \\
\hline Fernandes et al. [26] & $\begin{array}{c}\text { controlled } \\
\text { intervention study }\end{array}$ & $\begin{array}{l}\text { Healthy food patterns } \\
\text { education }\end{array}$ & 2 weeks & $\begin{array}{l}\text { Reducing the use of artificial juices, } \\
\text { increasing overweight and obesity in } \\
\text { the intervention group compared } \\
\text { tocontrol group, increased } \\
\text { consumption of mass-produced snacks } \\
\text { and soda and reduced breakfast cereal } \\
\text { consumption in school in the control } \\
\text { group }\end{array}$ \\
\hline Stock et al. [27] & pilot study & $\begin{array}{l}\text { Healthy food pattern } \\
\text { education, physical } \\
\text { activity }\end{array}$ & 21 weeks & $\begin{array}{l}\text { increase in knowledge, behavior, and } \\
\text { attitude } \\
\text { scores in healthy-living and a lower } \\
\text { increase in systolic blood pressure. } \\
\text { Less increase in BMI and weight } \\
\text { in the intervention older students and } \\
\text { height in the intervention younger } \\
\text { students }\end{array}$ \\
\hline Hollar et al. [28] & $\begin{array}{c}\text { quasi-experimental } \\
\text { design }\end{array}$ & $\begin{array}{l}\text { Diet, healthy food } \\
\text { patterns training and } \\
\text { increased physical } \\
\text { activity }\end{array}$ & 2 years & $\begin{array}{c}\text { No significant change in BMI, but } \\
\text { increase in the scores of the math } \\
\text { lesson }\end{array}$ \\
\hline
\end{tabular}


Table 1 continued. Intervention studies evaluating the effect of interventions on BMI, obesity and other criteria

\begin{tabular}{|c|c|c|c|c|}
\hline Author [Ref.] & Study & Intervention & $\begin{array}{l}\text { Duration of } \\
\text { intervention }\end{array}$ & Result \\
\hline Kain et al. [29] & controlled study & $\begin{array}{l}\text { Healthy eating pattern, } \\
\text { increased physical } \\
\text { activity and encouraging } \\
\text { interventions }\end{array}$ & 6 months & $\begin{array}{l}\text { Decreased BMI, Z-SCORE and waist } \\
\text { circumference }\end{array}$ \\
\hline Going et al. [30] & randomized trial & $\begin{array}{l}\text { Providing healthy diet, } \\
\text { healthy food pattern } \\
\text { training and physical } \\
\text { activity }\end{array}$ & 2 years & $\begin{array}{l}\text { Increased mobility in boys compared } \\
\text { to girls }\end{array}$ \\
\hline Sahota et al. [31] & $\begin{array}{l}\text { randomized } \\
\text { controlled crossover } \\
\text { trial }\end{array}$ & $\begin{array}{l}\text { Education for lifestyle, } \\
\text { food pattern and } \\
\text { physical activity } \\
\text { modification }\end{array}$ & 12 months & $\begin{array}{c}\text { Increasing the consumption of } \\
\text { vegetables, reducing the consumption } \\
\text { of food in obese children, consuming } \\
\text { food or sugar in overweight children, } \\
\text { and no significant difference in BMI } \\
\text { and diet pattern behavior }\end{array}$ \\
\hline Taylor et al. [33] & $\begin{array}{l}\text { controlled } \\
\text { community } \\
\text { intervention }\end{array}$ & $\begin{array}{l}\text { Food and healthy } \\
\text { lifestyle education }\end{array}$ & 2 years & $\begin{array}{l}\text { Decreased BMI, waist circumference, } \\
\text { systolic blood pressure and carbonated } \\
\text { beverages consumption and increased } \\
\text { consumption of fruits and juices }\end{array}$ \\
\hline Tarro et al. [34] & $\begin{array}{l}\text { randomized } \\
\text { controlled trial }\end{array}$ & $\begin{array}{l}\text { Education and } \\
\text { promotion of healthy } \\
\text { diet and physical } \\
\text { activity }\end{array}$ & 3 years & $\begin{array}{l}\text { Reduced prevalence of obesity and } \\
\text { decreased BMI Z-score amongboys in } \\
\text { intervention group }\end{array}$ \\
\hline Kocken et al. [35] & $\begin{array}{l}\text { randomized } \\
\text { controlled }\end{array}$ & $\begin{array}{l}\text { Physical activity, } \\
\text { training and promoting } \\
\text { a healthy diet, reducing } \\
\text { TV watching time and } \\
\text { reducingcomputer } \\
\text { games }\end{array}$ & 2 years & $\begin{array}{l}\text { Increased student awareness, } \\
\text { increased mobility }\end{array}$ \\
\hline Perman et al. [36] & Field Trial & $\begin{array}{l}\text { Healthy food patterns } \\
\text { education, physical } \\
\text { activity }\end{array}$ & 1 year & $\begin{array}{l}\text { Reduction in weight gain and } \\
\text { significant change in BMI }\end{array}$ \\
\hline Jansen et al. [37] & $\begin{array}{l}\text { cluster randomized } \\
\text { controlled }\end{array}$ & $\begin{array}{l}\text { Healthy food patterns } \\
\text { and physical activity }\end{array}$ & One school year & $\begin{array}{l}\text { Reduced weight gain, reduced waist } \\
\text { circumference and increased athletic } \\
\text { skills }\end{array}$ \\
\hline Rito et al. [38] & $\begin{array}{l}\text { Effectiveness } \\
\text { Trial }\end{array}$ & $\begin{array}{l}\text { Healthy food pattern } \\
\text { and physical activity } \\
\text { education }\end{array}$ & 6 months & $\begin{array}{l}\text { Increasing fruit and vegetable } \\
\text { consumption per day, increasing fiber } \\
\text { consumption and reducing soft drinks, } \\
\text { increasing physical activity and } \\
\text { reducing TV watching }\end{array}$ \\
\hline $\begin{array}{l}\text { Bacardi-Gascon et al. } \\
{[40]}\end{array}$ & $\begin{array}{l}\text { randomized cluster } \\
\text { controlled trial }\end{array}$ & $\begin{array}{l}\text { Healthy food pattern } \\
\text { education }\end{array}$ & 18 months & $\begin{array}{l}\text { Decreased BMI in the first 6months, } \\
\text { but increased BMI and ZSCORE and } \\
\text { waist circumference. Abdominal } \\
\text { obesity, increased intake of vegetables } \\
\text { and fruits, reduced inhibition, and } \\
\text { reduced consumption of high fat and } \\
\text { salt snacks }\end{array}$ \\
\hline Klish et al. [41] & $\begin{array}{l}\text { Randomized } \\
\text { controlled trial }\end{array}$ & $\begin{array}{l}\text { Food pattern training, } \\
\text { physical activity and } \\
\text { nutrition }\end{array}$ & 1 year & $\begin{array}{l}\text { Increased prevalence of overweight } \\
\text { and obesity }\end{array}$ \\
\hline Safdie et al. [42] & $\begin{array}{l}\text { randomized control } \\
\text { trial }\end{array}$ & $\begin{array}{l}\text { Physical activity and } \\
\text { nutrition }\end{array}$ & 2 year & $\begin{array}{l}\text { Increased consumption of healthy } \\
\text { foods, physical activity, and sports } \\
\text { information and reducedthe incidence } \\
\text { of obesity }\end{array}$ \\
\hline
\end{tabular}

intervention. A classroom-based intervention (happy 10 program) used to promote physical activity among primary school students. That program consisted of a variety of safe, moderate, age- and space-appropriate exercises that was included 2 times a day, 10 minutes per time, or 1 time a day and 20 minutes per time. The results showed that the program were accepted by the schools, teachers, and students and its implementation is easy.

In a study by Bacardi-Gascon et al. [40], 
intervention on three fields was assessed during 18 months: (1) training school board and teachers (three 60-minute sessions by nutritionists and sports professionals for teachers and school officials to discuss about healthy lifestyles, how to improve school meals and snacks in the cafeterias, and how to improve physical activity in school and outside school), (2) improving classroom curriculum (the classroom curricula for $2^{\text {nd }}$ and $3^{\text {rd }}$ grades designed to promote healthful eating behaviors and to increase physical activity like reducing the consumption of beverages and soft drinks, fat and sugar, and increasing fruit and vegetables consumption, increasing physical activity for 30 minutes each week for 8 weeks during the year, reducing screen time, and assessing food consumption and physical activity among children), and (3) parent involvement (the purpose of it, was to inform them of the intervention program and provide nutrition education and to develop their knowledge on healthy lifestyle and eating behavior of parents, which consisted of four 60 minute sessions that were conducted by nutritionists each month during a year). The results showed BMI decrease (-0.82) after six-month, BMI and waist circumference $\mathrm{z}$-score increase after 24 months, and $8 \%$ decrease in abdominal obesity and $18 \%$ increase in overweight and obesity. Additionally, increased intake of vegetables and physical activity reduced sedentary activities and consumption of high fats and salts snacks have been reported.

Klish et al. [41] performed a study with the aim of determining the effectiveness of a school-initiated cognitive and behavioral program to reduce childhood obesity. The study was conducted on one-year education-based interventions (including 30 minutes of nutrition education, outside school hours, nutrition classes for changing habits such as selecting less volume of drinks and food, children's favorite fruits and vegetables in the daily diet, and playing video on healthy eating and teaching food labels), physical activity (including 30 minutes of physical activity and proper physical activity for cardiovascular health such as jumping, ball games in open space, team games and play in the school environment and after school hours, football, karate and dancing) and nutrition (providing healthy meals and 2-3 fruit snacks in the school). The results of that study showed the prevalence of overweight and obesity was $18.9 \%$ and $30.4 \%$ versus
$19 \%$ and $30.2 \%$, respectively, in the intervention and control schools. Also, in the control school, the incidence of overweight increased, but the incidence of obesity, weight, and BMI z-scores increased significantly in the intervention school.

\section{Nutrition-based and Physical Activity Interventions to Prevent Obesity}

In a two-year study by Safdie et al. [42], the results of physical activity-based interventions (including increased physical activity time at school and holding sports classes at resting hours) and nutrition (including increased fruit and vegetables consumption and available mineral water and reducing high-calorie food available) were examined. The results showed that the selection and consumption of healthy foods, physical activity and sports information increased by children and the prevalence of overweight and obesity decreased.

Intervention studies evaluating the effect of interventions on BMI, obesity and other criteria are summarized in Table 1.

\section{DISCUSSION}

The purpose of this review was to answer the question whether implementing single interventions such as increasing physical activity, nutrition education, physical activity and or improving child nutrition behaviors, such as supervision of school buffets for the supply of healthy foods can help to reduce obesityor it is better to implement multidisciplinary interventions.

In the investigating of the effect of physical activity interventions on BMI, one study [17] has shown that physical activity has a significant difference in the reduction of BMI in the intervention group compared to control one, but in another study [18], the change in BMI was not significant in the two groups, but showed significant reduction on skin thickness and body fat percentage in both genders. In another study [19], this intervention reduced the percentage of body fat and improved cardiovascular and pulmonary function among students, but did not show any effect on LDL, HDL, and blood pressure. In another multidisciplinary study [20] that compulsory physical activity was included, the results indicated 
improved fitness, reduced fat accumulation and improved aerobic performance. All in all, it seems that interventions on the weight and BMI status have different and unpredictable effects. Seven studies have been done on the effects of education on nutrition and nutritional habits, increased physical activity and healthy lifestyle. One study [21] showed that physical activity education reduced BMI z-score and reduced the likelihood of obesity among 5 th grade elementary students, especially boys. In 5 studies [22, 24-27], it was also shown that educational intervention in a relatively short time period ( 2.5 to 4 months) does not have an effect on the reduction of obese students' BMI. But a study [23] showed that continuous training for parents and students on improving diet habits, increasing physical activity and reducing the time of watching television and computer games, after 1 year, resulted in a significant reduction in children's BMI. In general, the implementation of these types of interventions concluded that educational programs for students, parents and school officials could have a positive impact on the weight loss of obese children, if they were continued and in the long term (at least one year). Other interventions that have considered both increasing physical activity and education as two effective strategies, have shown the greater impact of these multidisciplinary interventions.In these types of interventions, school officials, teachers, students and their parents, food service providers and school buffet operators, trained to provide healthy food products such as non-sugar drinks, milk and lean yogurt, fresh and dried fruits, sugar-free biscuits and low-calorie snacks. In two studies $[28,30]$, which used more than 90 minute physical activity per day, no significant difference was shown among children.

However, in a similar study [29] which lasted for six months, mixing encouraging interventions (awarding students who consumed healthy food during one day) with the above-mentioned interventions had a positive effect on BMI and z-score, but not for the thickness of skinfold. It can be concluded from these interventions that physical activity and education alone cannot be effective in decreasing BMI, even in the long term, and it is necessary to consider simultaneous enhancement of children's physical activity and the use of encouraging tools.

Nine studies [33-41] were investigated the simultaneous impact of education, nutrition and physical activity interventions on weight loss and dietary modification and lifestyle. The results of the studies indicated that the probability of success of these interventions is greater if the multidisciplinary method is used. On the other hand, in the nutritional behaviors and BMI, the duration of the intervention is very important, and accessing to a good outcome is very likely in interventions which last for more than 1 year. In multiple interventions, due to the multiplicity of outcomes, there have been significant improvements at least in one of the three outcomes of increased awareness, nutritional behaviors and weight status.

Two studies were conducted to determine the effect of simultaneous physical and nutritional interventions. In one study [42], these interventions increased physical activity and sports information, increased consumption and choice of healthy foods, and decreased overweight and obesity rates, during two years of implementation. The study showed that direct interventions on nutritional behaviors by providing favorable conditions, improve the studied indicators.

\section{CONCLUSION}

In reviewing the implemented programs, the reports show that the schools are very suitable environments for implementing weight control interventions. However, in all the reports, there is almost an emphasis on the need for multidimensional and holistic interventions. Since the school environment exposes all children to interventions, it can also reduce peer pressure, which psychologically prepares children to change. After school, the most important issue is the home and the family, due to the strong emotional relationships, the possibility of inducing correct behaviors and strengthening them. Finally, the socio-cultural context of the society is also at a level that can facilitate change by creating the right conditions for physical activity, the availability of healthy foods, and the provision of appropriate incentive messages.

In general, the following factors can be considered as the most important factors involved in the adoption of healthy behaviors: (1) Training: Includes training 
for teachers, coaches, parents, children and school buffet and catering staff, (2) Proper environmental conditions: Healthy buffets in schools; An irritating, refreshing and elegant dining room with an adequate time to eat; Having enough space and time for physical activity; Providing encouragement for healthy behaviors, and (3) Designing an interventional program with the participation of all stakeholders: School administrators, trainers and teachers; Parents and children of around society (Child's social circle).

\section{Conflict of interest}

The authors disclosed no conflict of interest during the preparation or publication of this manuscript.

\section{Financing}

The authors disclosed that they did not receive any grant during conduction or writing of this study.

\section{REFERENCES}

1. Pangani IN, Kiplamai FK, Kamau JW, Onywera VO. Prevalence of overweight and obesity among primary school children aged 8-13 years in Dar es Salaam City, Tanzania. Adv Prev Med 2016;2016:1345017.

2. Ng M, Fleming T, Robinson M, Thomson B, Graetz N, Margono C, et al. Global, regional, and national prevalence of overweight and obesity in children and adults during 1980-2013: a systematic analysis for the Global Burden of Disease Study 2013. Lancet 2014;384:766-81.

3. Katzmarzyk PT, Janssen I. The economic costs associated with physical inactivity and obesity in Canada: an update. Can J Appl Physiol 2004;29:90-115.

4. WHO. Obesity and Overweight 2017. Available from: http://www.who.int/mediacentre/factsheets/fs311/en/.

5. Kumar S, Mahabalaraju DK, Anuroopa MS. Prevalence of obesity and its influencing factor among affluent school children of Davangere city. Indian J Community Med 2007;32:15-17.

6. Doak CM, Visscher TL, Renders CM, Seidell JC. The prevention of overweight and obesity in children and adolescents: a review of interventions and programmes. Obes Rev 2006;7:11136.

7. Crawford D. Population strategies to prevent obesity. BMJ (Clinical research ed) 2002;325:728-9.

8. Taheri F, Kazemi T, Sadeghi H. Prevalence of overweight and obesity among primary school children in Iran from 2001-2013: a systematic review. Mod Care J 2015;12:139-45.

9. Siassi F, Mohammad K, Djazayery A, Djalali M, Abdollahi Z, Dorosty A, et al. National Integrated Micronutrient Survey 2012 (NIMS II) 2015.

10. Motlagh ME, Ziaoddini H, Yamani T, Taheri M, Kelishadi R,
Heshmat R, et al. Childhood and adolescences surveillance and prevention of adult non-communicable disease (CASPIAN 5). Isfahan: 2016.

11. Dietz WHJ. Implications and treatment of adolescent obesity AGRIS 1985.

12. Muller MJ, Asbeck I, Mast M, Langnase K, Grund A. Prevention of obesity--more than an intention. Concept and first results of the Kiel Obesity Prevention Study (KOPS). Int J Obes Relat Metab Disord 2001;25 Suppl 1:S66-74.

13. Foster GD, Sherman S, Borradaile KE, Grundy KM, Vander Veur SS, Nachmani J, et al. A policy-based school intervention to prevent overweight and obesity. Pediatrics 2008;121:e794-802. 14. Harris KC, Kuramoto LK, Schulzer M, Retallack JE. Effect of school-based physical activity interventions on body mass index in children: a meta-analysis. CMAJ 2009;180:719-26.

15. Brown EC, Buchan DS, Baker JS, Wyatt FB, Bocalini DS, Kilgore L. A systematised review of primary school whole class child obesity interventions: effectiveness, characteristics, and strategies. Biomed Res Int 2016;2016:4902714.

16. Seo NS, Kim YH, Kang HY. [Effects of an obesity control program based on behavior modification and self-efficacy in obese elementary school children]. Taehan Kanho Hakhoe Chi 2005;35:611-20. [Article in Korean]

17. Donnelly JE, Greene JL, Gibson CA, Smith BK, Washburn RA, Sullivan DK, et al. Physical Activity Across the Curriculum (PAAC): a randomized controlled trial to promote physical activity and diminish overweight and obesity in elementary school children. Prev Med 2009;49:336-41.

18. Elizondo-Montemayor L, Gutierrez NG, Moreno DM, Martinez U, Tamargo D, Trevino M. School-based individualised lifestyle intervention decreases obesity and the metabolic syndrome in Mexican children. J Hum Nutr Diet 2013;26 Suppl 1:82-9.

19. Yin Z, Moore JB, Johnson MH, Vernon MM, Gutin B. The impact of a 3-year after-school obesity prevention program in elementary school children. Child Obes 2012;8:60-70.

20. Kriemler S, Zahner L, Schindler C, Meyer U, Hartmann T, Hebestreit H, et al. Effect of school based physical activity programme (KISS) on fitness and adiposity in primary schoolchildren: cluster randomised controlled trial. BMJ (Clinical research ed) 2010;340:c785.

21. Cawley J, Frisvold D, Meyerhoefer C. The impact of physical education on obesity among elementary school children. J Health Econ 2013;32:743-55.

22. Lynch BA, Gentile N, Maxson J, Quigg S, Swenson L, Kaufman T. Elementary school-based obesity intervention using an educational curriculum. J Prim Care Community Health. 2016;7:265-71.

23. Toruner EK, Savaser S. A controlled evaluation of a schoolbased obesity prevention in Turkish school children. J Sch Nurs 2010;26:473-82.

24. Fairclough SJ, Hackett AF, Davies IG, Gobbi R, Mackintosh KA, Warburton GL, et al. Promoting healthy weight in primary school children through physical activity and nutrition education: a pragmatic evaluation of the CHANGE! randomised intervention study. BMC Public Health 2013;13:626.

25. Xu F, Ware RS, Leslie E, Tse LA, Wang Z, Li J, et al. 
Effectiveness of a randomized controlled lifestyle intervention to prevent obesity among Chinese primary school students: CLICKobesity study. PLoS One 2015;10:e0141421.

26. Fernandes PS, Bernardo Cde O, Campos RM, Vasconcelos FA. Evaluating the effect of nutritional education on the prevalence of overweight/obesity and on foods eaten at primary schools. J Pediatr (Rio J) 2009;85:315-21.

27. Stock S, Miranda C, Evans S, Plessis S, Ridley J, Yeh S, et al. Healthy Buddies: a novel, peer-led health promotion program for the prevention of obesity and eating disorders in children in elementary school. Pediatrics 2007;120:e1059-68.

28. Hollar D, Messiah SE, Lopez-Mitnik G, Hollar TL, Almon M, Agatston AS. Effect of a two-year obesity prevention intervention on percentile changes in body mass index and academic performance in low-income elementary school children. Am J Public Health 2010;100:646-53.

29. Kain J, Uauy R, Albala, Vio F, Cerda R, Leyton B. Schoolbased obesity prevention in Chilean primary school children: methodology and evaluation of a controlled study. Int J Obes Relat Metab Disord 2004;28:483-93.

30. Going S, Thompson J, Cano S, Stewart D, Stone E, Harnack $\mathrm{L}$, et al. The effects of the pathways obesity prevention program on physical activity in American Indian children. Prev Med 2003;37(6 Pt 2):S62-9.

31. Sahota P, Rudolf MCJ, Dixey R, Hill AJ, Barth JH, Cade J. Randomised controlled trial of primary school based intervention to reduce risk factors for obesity. BMJ (Clinical research ed) 2001;323:1029.

32. Bustos N, Olivares S, Leyton B, Cano M, Albala C. Impact of a school-based intervention on nutritional education and physical activity in primary public schools in Chile (KIND) programme study protocol: cluster randomised controlled trial. BMC Public Health 2016;16.

33. Taylor RW, McAuley KA, Barbezat W, Strong A, Williams SM, Mann JI. APPLE Project: 2-y findings of a communitybased obesity prevention program in primary school age children. Am J Clin Nutr 2007;86:735-42.
34. Tarro L, Llauradó E, Albaladejo R, Moriña D, Arija V, Solà $\mathrm{R}$, et al. A primary-school-based study to reduce the prevalence of childhood obesity - the EdAl (Educació en Alimentació) study: a randomized controlled trial. Trials 2014;15:58.

35. Kocken PL, Scholten AM, Westhoff E, De Kok BPH, Taal EM, Goldbohm RA. Effects of a theory-based education program to prevent overweightness in primary school children. Nutrients 2016;8(1). pii:E12.

36. Perman JA, Young TL, Stines E, Hamon J, Turner LM, Rowe MG. A community-driven obesity prevention and intervention in an elementary school. J Ky Med Assoc 2008;106:104-8.

37. Jansen W, Borsboom G, Meima A, Zwanenburg EJ, Mackenbach JP, Raat H, et al. Effectiveness of a primary schoolbased intervention to reduce overweight. Int J Pediatr Obes 2011;6:e70-7.

38. Rito AI, Carvalho MA, Ramos C, Breda J. Program Obesity Zero (POZ) - a community-based intervention to address overweight primary-school children from five Portuguese municipalities. Public Health Nutr 2013;16:1043-51.

39. Li Y, Hu X, Zhang Q, Liu A, Fang H, Hao L, et al. The nutrition-based comprehensive intervention study on childhood obesity in China (NISCOC): a randomised cluster controlled trial. BMC Public Health 2010;10:229.

40. Bacardi-Gascon M, Perez-Morales ME, Jimenez-Cruz A. A six month randomized school intervention and an 18-month follow-up intervention to prevent childhood obesity in Mexican elementary schools. Nutr Hosp 2012;27:755-62.

41. Klish WJ, Karavias KE, White KS, Balch AJ, Fraley JK, Mikhail C, et al. Multicomponent school-initiated obesity intervention in a high-risk, Hispanic elementary school. J Pediatr Gastroenterol Nutr 2012;54:113-6.

42. Safdie M, Levesque L, Gonzalez-Casanova I, Salvo D, Islas A, Hernandez-Cordero S, et al. Promoting healthful diet and physical activity in the Mexican school system for the prevention of obesity in children. Salud Publica Mex 2013;55 Suppl 3:35773. 